\title{
Spectroscopic Determination of Some Trace Elements as Pollutants in Fish
}

\author{
A.B. EI Bialy, S.S. Hamed, W.M.Moussa and R.K. Abd El-Hameed \\ Physics Department Faculty of Girls of Science and Arts, \\ Ain Shams University, Cairo, Egypt
}

Research was undertaken to determine the trace element concentrations in foodstuff and check pollution. The Samples under investigation represent different types of fish muscle tissue. They were collected from fresh water and seawater for a period of two years. The present work is carried out using Atomic Absorption Spectrometer, two digestive methods were investigated for sample dissolution, dry ash and wet ash method. The determined elements were $\mathrm{Cd}, \mathrm{Cu}, \mathrm{Fe}, \mathrm{Mn}, \mathrm{Ni}, \mathrm{Pb}$ and $\mathrm{Zn}$. The analytical as well as standard addition curves were used to determine the elements concentration in different samples.

\section{Introduction:}

Determination of trace elements is considered as a useful and important test in surveys of environmental pollution. The levels of some elements can be related to various pathological conditions in man. There are no toxic elements but only toxic concentrations. Even essential trace elements can cause damage to health or even death at increased concentrations. The form in which an element is ingested also plays a major role in its restorability or toxicity. Therefore, the results obtained to the diagnosis and treatment of particular diseases $(1,2)$.

Among the available trace analytical techniques the powerful flame atomic absorption spectrometer (FAAS) for the determination of elements concentration in different samples. $(3,4,5,6)$ Relative freedom from spectral interference and linear dynamic range inherited with this method as well as the low limits of detection allow the determination of major, minor and trace elements.

One of the drawbacks of industrial revolution is the transformation of lakes, rivers into sewage depots where the natural biological balance is severely upset and in some cases totally disrupted. For the evaluation of the present 
status of our environment with respect to hazardous chemical and toxic element, fish samples were chosen for this study as it reflects the pollution of the water.

The aim of the present work is the determination of the trace elements concentration in different kinds of fish muscle tissue. The samples were collected from three different areas Musturod, Manial - as example of fresh water and Suez Canal as seawater over a period of two years, summer from 1998 to autumn 2000.

\section{Experiment:}

\subsection{Sample Preparation:}

Although different solid sample introduction techniques have been developed $(7,8,9)$ solution nebulization remains the most widely used technique. This is because of the homogeneous sample solution used and the ease of preparation of calibration standards. Two digestion methods were investigated for a reliable dissolution procedure, wet and dry ash methods.

\subsection{Dry ash Method:}

In the present work 25gm of wet tissue in a porcelain crucible were dried at $135 c^{\circ}$ for 2 hours to obtain dry weight. Then transferred to a cool muffle furnace and slowly raise the temperature to $450-500 c^{\circ}$ overnight. After cooling $2 \mathrm{ml}$ conc. $\mathrm{HNO}_{3}$ were added and swirl the crucible. The sample was then heated on hot plate until dryness. Again it was returned to the cooled furnace and the temperature was raised to 450-500co for an hour. After cooling $10 \mathrm{ml}$ of $1 \mathrm{~N} \mathrm{HCL}$ were added and heating on the hot plate then dissolved ash. Then the solution was transferred into $25 \mathrm{ml}$ volumetric flask and completed to volume by bi-distilled water.

\subsection{Wet ash Method:}

The employed procedure was as follows: 2gm of dry tissue sample and $2.5 \mathrm{ml} \mathrm{HNO}_{3}$ were heated in a beaker on a hot plate until evaporated to near dryness. Further $2.5 \mathrm{ml}$ of $\mathrm{HNO}_{3}$ were added to residue and evaporated to near dryness to ensure the complete dissolution; bi-distilled water was then added to the residue which could be dissolved to clear solution. The solution was then transferred into $25 \mathrm{ml}$ volumetric flask and completed to volume.

\subsection{Instrumentation and Optimal Condition:}

Perken - Elmer flame atomic absorption spectrometer, FAAS, (model 2380) equipped with burner- nebulizer for air- acetylene having single slot 100 
mm was used for carrying out the analysis. Table (1) illustrates the operating condition used.

Table (1): The operating conditions used for the spectrometer

\begin{tabular}{|c|c|c|}
\hline Element & Wavelength & Slit band width (mm) \\
\hline $\mathrm{Mn}$ & 279.5 & 0.2 \\
$\mathrm{Zn}$ & 213.9 & 0.7 \\
$\mathrm{Cd}$ & 228.8 & 0.7 \\
$\mathrm{~Pb}$ & 283.3 & 0.7 \\
$\mathrm{Ni}$ & 232.0 & 0.2 \\
$\mathrm{Fe}$ & 248.3 & 0.2 \\
$\mathrm{Cu}$ & 324.8 & 0.7 \\
\hline
\end{tabular}

\subsection{Optimal Conditions:}

The absorbance of an analytic line is a function of several parameters, burner head position (vertical, horizontal) and flow rate of the used gases. Optimal values of these parameters are those, which yield maximum absorbance value. The optimization procedure was carried out by studying the effect of one parameter while keeping the others constants at appropriate values. For this study $\mathrm{Ni}$ and $\mathrm{Mn}$ were selected as an example.

\subsection{Vertical and Horizontal Position of the Burner Head:}

To carry out this study the acetylene and airflow rate were kept constant at $2 \mathrm{~L} / \mathrm{min}$ and $19.5 \mathrm{~L} / \mathrm{min}$ respectively. Fig (1) illustrates the effect of burner height on the absorbance of the spectral line. It can be seen from the Fig. that the best values of the vertical and horizontal position of the burner head are 20 and $17.5 \mathrm{~mm}$ respectively from the base of the burner. 


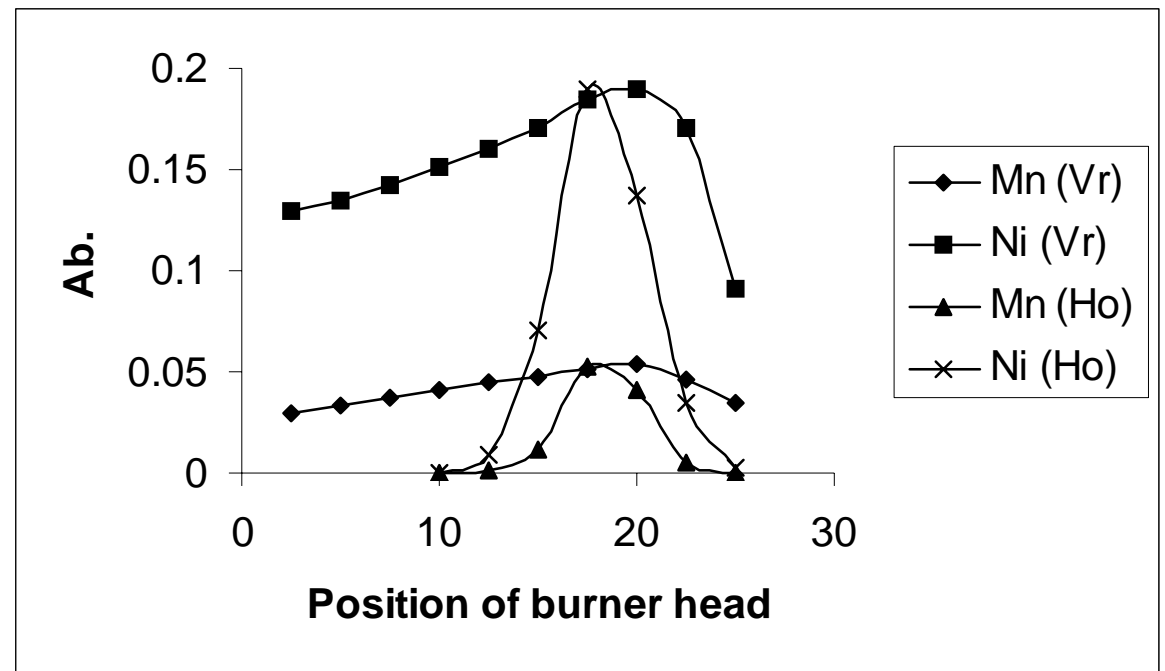

Fig (1): Effect of burner head position (vertical (Vr) and horizontal (Ho)) on absorbance of Mn and Ni.

\subsection{Flow Rate Effect of Fuel and Oxidant Gases:}

It is obvious that the aerosol flow rate governs the amount of elements introduced to the flame as well as the velocity of the gases in the flame. Fig. $(2,3)$ shows the effect of the flow rate for the fuel gas (acetylene) and oxidant gas (air). It is clear that the optimal values for the fuel and oxidant gas respectively are $0.7 \mathrm{~L} / \mathrm{min}$ and $9.35 \mathrm{~L} / \mathrm{min}$.

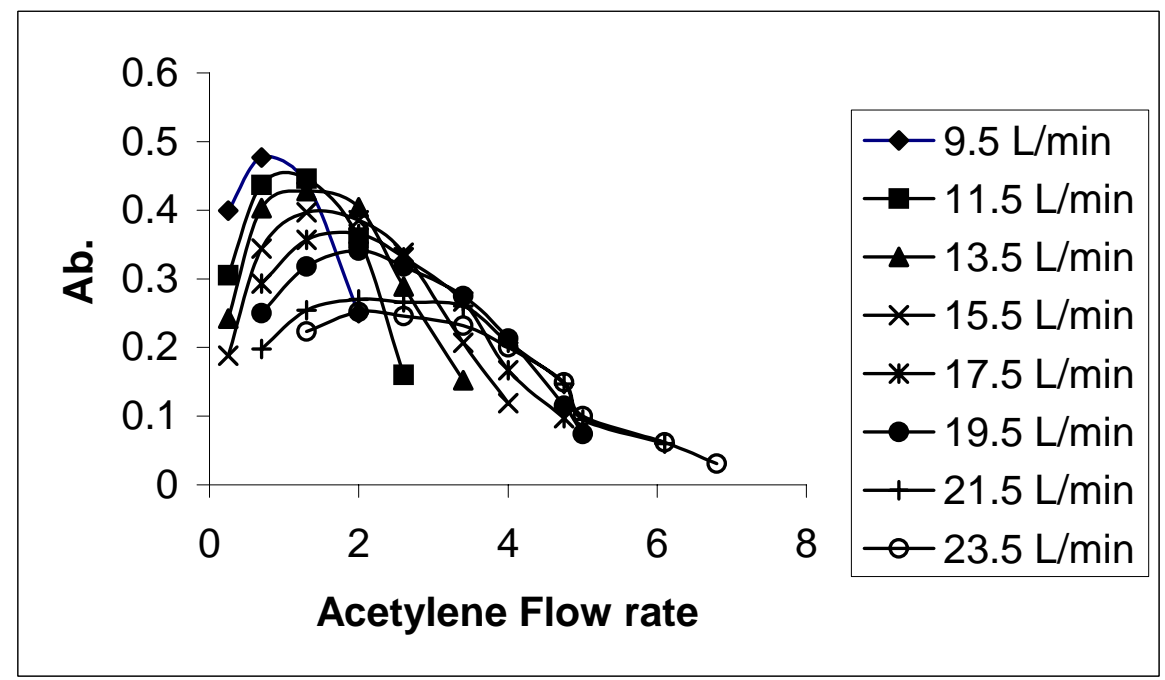

Fig.(2): Effect of Acetylene flow rate on absorbance of Mn at constant Airflow rate. 


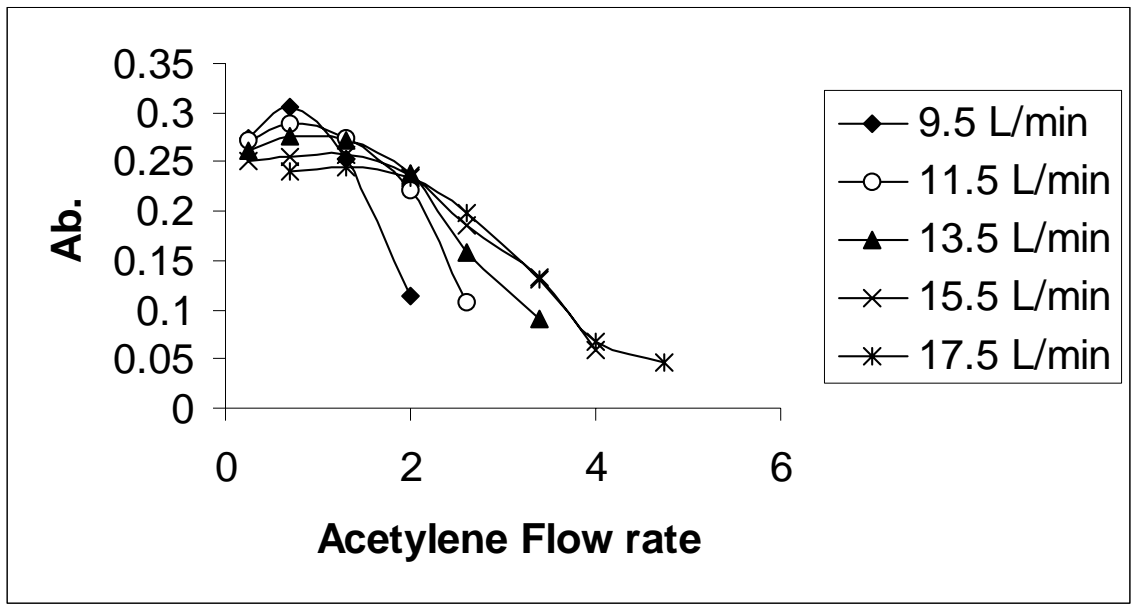

Fig.(3): Effect of Acetylene flow rate on absorbance of $\mathrm{Ni}$ at constant Airflow rate.

\section{Results and Discussion:}

Under the optimized conditions given in Table (1), analytical calibration curves were obtained by using freshly prepared standard solutions for every element (Cd, $\mathrm{Cu}, \mathrm{Fe}, \mathrm{Mn}, \mathrm{Ni}, \mathrm{Pb}$ and $\mathrm{Zn}$ ). The standard solutions were simply prepared by suitable dilution from stock solution containing $1000 \mu \mathrm{g} / \mathrm{ml}$ for every element. Calibration is done with aqueous standards. Figures ( $4 \& 5$ ) show the plots of the analytical curves for the seven metals.

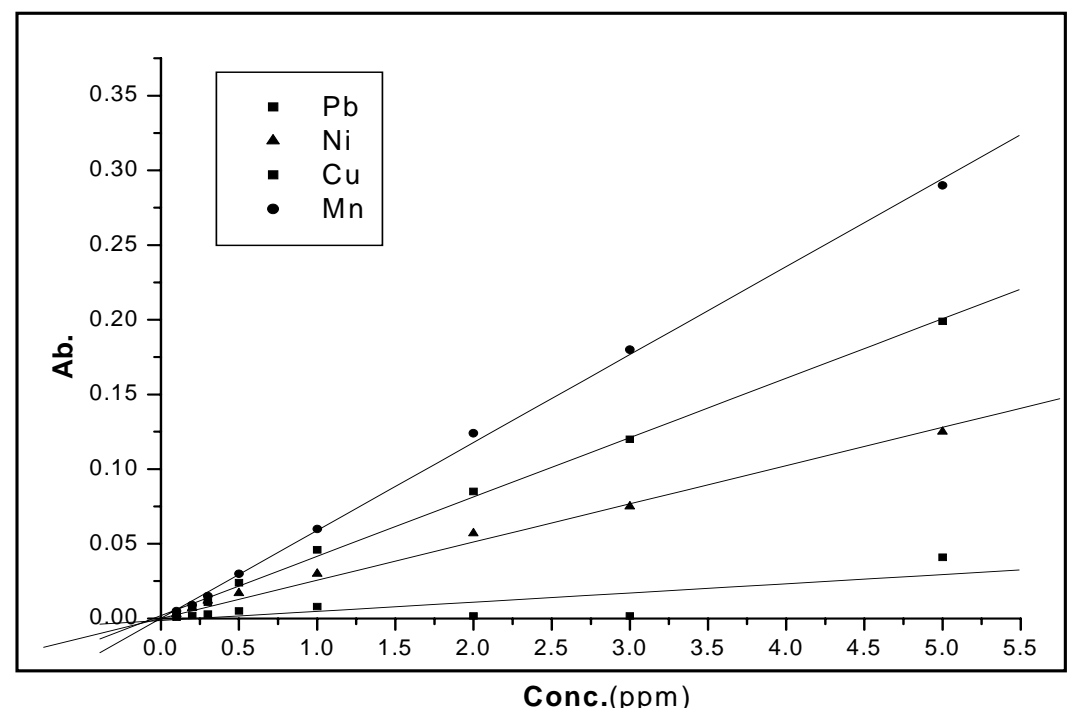

Fig. (4) : Analytical calibration curve for $\mathrm{Cu}, \mathrm{Mn}, \mathrm{Ni}$ and $\mathrm{Pb}$. 


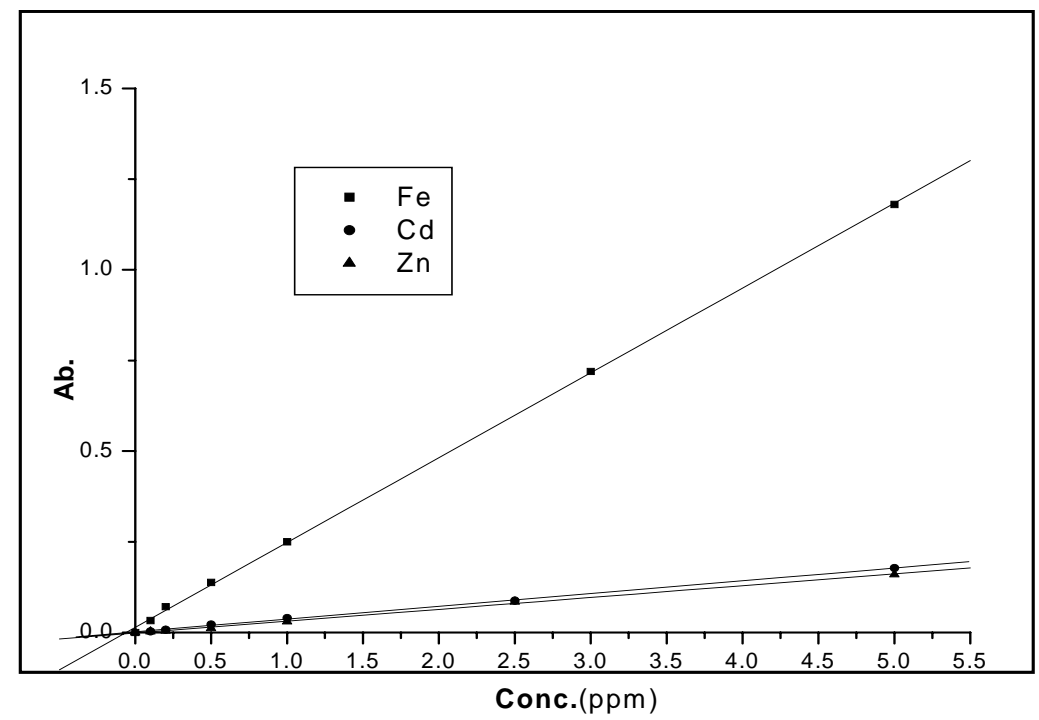

Fig. (5): Analytical calibration curve for $\mathrm{Cd}$, Fe and Zn.

To construct the standard addition curve, the sample solutions were spiked by a series of concentrations of the elements to be determined. In this method the sample solution prepared by wet ash method was used. Example of such curve for ash is shown in Fig.(6), it can be seen from the fig., that the analytical calibration and standard addition curves obtained are linear over the used range of concentrations. For all elements, tables $(2,3)$ show the concentrations obtained.

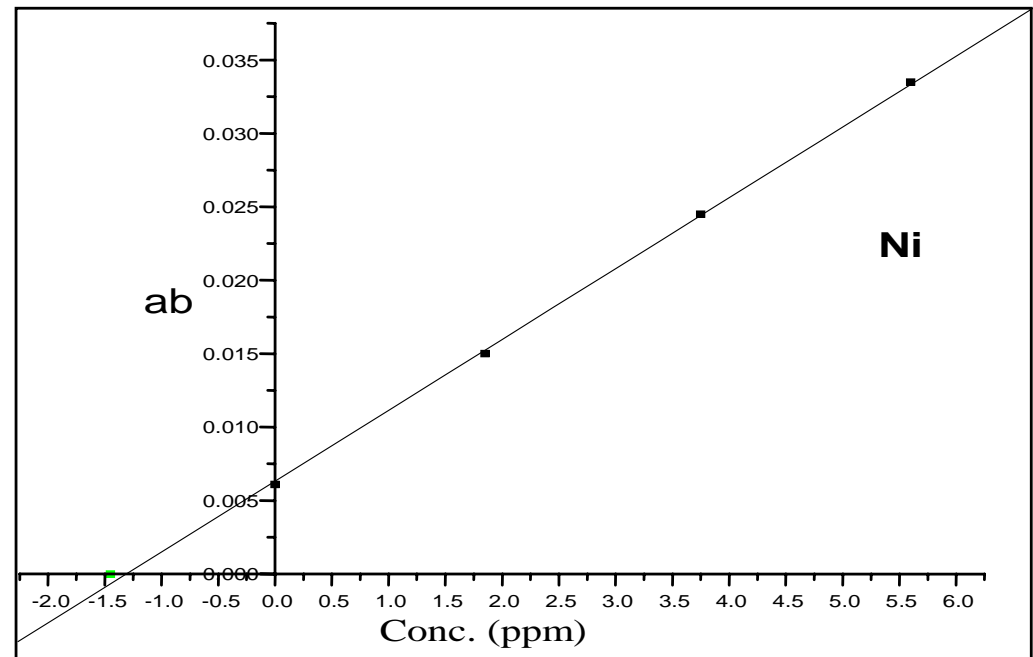

Fig. (6): Standard addition curve for Ni. 
Table (2): Concentration of the determined elements in fresh water $(\mathrm{N})$ and seawater (S) samples during (1998):

(a) Dry ash method.

\begin{tabular}{|c|c|c|c|c|c|c|c|}
\hline $\begin{array}{c}\text { Sample } \\
\mathbf{N o .}\end{array}$ & $\begin{array}{c}\mathbf{Z n} \\
(\mu \mathrm{g} / \mathrm{g})\end{array}$ & $\begin{array}{c}\mathbf{C u} \\
(\mu \mathrm{g} / \mathrm{g})\end{array}$ & $\begin{array}{c}\mathbf{F e} \\
(\mu \mathrm{g} / \mathrm{g})\end{array}$ & $\begin{array}{c}\mathbf{M n} \\
(\mu \mathrm{g} / \mathrm{g})\end{array}$ & $\begin{array}{c}\mathbf{P b} \\
(\mu \mathrm{g} / \mathrm{g})\end{array}$ & $\begin{array}{c}\mathbf{C d} \\
(\mu \mathrm{g} / \mathrm{g})\end{array}$ & $\begin{array}{c}\mathbf{N i} \\
(\mu \mathrm{g} / \mathrm{g})\end{array}$ \\
\hline $\mathbf{1 N}$ & 24.54 & 6.50 & 29.8 & 4.57 & 2.33 & 3.25 & 1.77 \\
\hline $\mathbf{2 N}$ & 17.98 & 3.46 & 37.50 & 7.9 & 1.70 & 2.22 & 0.93 \\
\hline $\mathbf{3 N}$ & 19.5 & 11.40 & 27.60 & 2.17 & 1.55 & 2.52 & 0.41 \\
\hline $\mathbf{4 N}$ & 10.5 & 7.40 & 16.20 & 3.64 & 3.11 & ---- & ----- \\
\hline $\mathbf{5 N}$ & 13.68 & 4.32 & 12.80 & 1.60 & 2.20 & 4.25 & ----- \\
\hline $\mathbf{6 N}$ & 12.31 & 5.60 & 17.70 & 1.60 & 1.98 & 2.67 & ----- \\
\hline $\mathbf{1 S}$ & 28.21 & 10.51 & 22.25 & 6.90 & 1.24 & 2.00 & 0.87 \\
\hline $\mathbf{2 S}$ & 19.53 & 5.65 & 53.15 & 5.50 & 3.10 & 3.11 & 1.71 \\
\hline $\mathbf{3 S}$ & ----- & 2.17 & ---- & 3.22 & 1.86 & ----- & 2.76 \\
\hline
\end{tabular}

(b) Wet ash method.

\begin{tabular}{|c|c|c|c|c|c|c|c|}
\hline Sample No. & $\begin{array}{c}\mathbf{Z n} \\
(\mu \mathrm{g} / \mathrm{g})\end{array}$ & $\begin{array}{c}\mathbf{C u} \\
(\mu \mathrm{g} / \mathrm{g})\end{array}$ & $\begin{array}{c}\mathbf{F e} \\
(\mu \mathrm{g} / \mathrm{g})\end{array}$ & $\begin{array}{c}\mathbf{M n} \\
(\mu \mathrm{g} / \mathrm{g})\end{array}$ & $\begin{array}{c}\mathbf{P b} \\
(\mu \mathrm{g} / \mathrm{g})\end{array}$ & $\begin{array}{c}\mathbf{C d} \\
(\mu \mathrm{g} / \mathrm{g})\end{array}$ & $\begin{array}{c}\mathbf{N i} \\
(\mu \mathrm{g} / \mathrm{g})\end{array}$ \\
\hline $\mathbf{1 N}$ & 29.10 & 7.33 & 37.52 & 5.20 & 13.30 & 4.30 & 2.45 \\
\hline $\mathbf{2 N}$ & 23.42 & 5.99 & 44.80 & 8.06 & 9.10 & 3.15 & 2.96 \\
\hline $\mathbf{3 N}$ & 37.50 & 13.50 & 35.65 & 2.50 & 6.30 & 3.22 & 1.44 \\
\hline $\mathbf{4 N}$ & 15.40 & 10.52 & 18.71 & 5.10 & 3.70 & ---- & 2.40 \\
\hline $\mathbf{5 N}$ & 20.76 & 6.39 & 14.11 & 1.73 & 17.00 & 4.60 & 3.22 \\
\hline $\mathbf{6 N}$ & 15.31 & 7.12 & 19.52 & 2.10 & 12.30 & 2.95 & 2.07 \\
\hline $\mathbf{1 S}$ & 50.52 & 15.46 & 36.25 & 7.50 & 8.80 & 2.10 & 1.02 \\
\hline $\mathbf{2 S}$ & 21.64 & 9.22 & 66.70 & 5.90 & 4.85 & 3.75 & 2.30 \\
\hline $\mathbf{3 S}$ & ----- & 3.33 & ----- & 3.35 & 2.20 & ----- & 2.90 \\
\hline
\end{tabular}

1N: Karmot 2N: Bolty 3N: Keshrbyad 4N: Raash 5N: 6N: Anom

1S: Bory 2S: Makarona 3S: Bolty 
Table (3): Concentration of the determined elements in fresh water (N) and sea- water (S) samples during (2000).

(a) Dry ash method.

\begin{tabular}{|c|c|c|c|c|c|c|c|}
\hline Sample No. & $\begin{array}{c}\mathbf{Z n} \\
(\mu \mathrm{g} / \mathrm{g})\end{array}$ & $\begin{array}{c}\mathbf{C u} \\
(\mu \mathrm{g} / \mathrm{g})\end{array}$ & $\begin{array}{c}\mathbf{F e} \\
(\mu \mathrm{g} / \mathrm{g})\end{array}$ & $\begin{array}{c}\mathbf{M n} \\
(\mu \mathrm{g} / \mathrm{g})\end{array}$ & $\begin{array}{c}\mathbf{P b} \\
(\mu \mathrm{g} / \mathrm{g})\end{array}$ & $\begin{array}{c}\mathbf{C d} \\
(\mu \mathrm{g} / \mathrm{g})\end{array}$ & $\begin{array}{c}\mathbf{N i} \\
(\mu \mathrm{g} / \mathrm{g})\end{array}$ \\
\hline $\mathbf{1 N}$ & 22.17 & 5.66 & 13.30 & 4.03 & 2.10 & 2.48 & 1.62 \\
\hline $\mathbf{2 N}$ & 10.98 & 2.91 & 27.36 & 7.13 & 1.40 & 1.24 & 0.93 \\
\hline $\mathbf{3 N}$ & 18.29 & 9.80 & 21.70 & 1.96 & 1.86 & 1.87 & 0.31 \\
\hline $\mathbf{4 N}$ & 9.60 & 4.73 & 14.22 & ----- & 3.50 & ----- & ------ \\
\hline $\mathbf{5 N}$ & 11.70 & 3.10 & 9.60 & 1.55 & 1.70 & 4.30 & ------ \\
\hline $\mathbf{6 N}$ & 8.90 & 4.70 & 13.60 & 1.00 & 1.40 & 2.50 & ------ \\
\hline $\mathbf{1 S}$ & 9.82 & 8.41 & 19.90 & 7.02 & 1.55 & 1.24 & 0.62 \\
\hline $\mathbf{2 S}$ & 13.47 & 3.30 & 44.81 & 4.30 & 2.33 & 2.79 & 1.46 \\
\hline $\mathbf{3 S}$ & ----- & 1.87 & ----- & 2.50 & 1.40 & ---- & 2.00 \\
\hline
\end{tabular}

(b) Wet ash method.

\begin{tabular}{|c|c|c|c|c|c|c|c|}
\hline Sample No. & $\begin{array}{c}\mathbf{Z n} \\
(\mu \mathrm{g} / \mathrm{g})\end{array}$ & $\begin{array}{c}\mathbf{C u} \\
(\mu \mathrm{g} / \mathrm{g})\end{array}$ & $\begin{array}{c}\mathbf{F e} \\
(\mu \mathrm{g} / \mathrm{g})\end{array}$ & $\begin{array}{c}\mathbf{M n} \\
(\mu \mathrm{g} / \mathrm{g})\end{array}$ & $\begin{array}{c}\mathbf{P b} \\
(\mu \mathrm{g} / \mathrm{g})\end{array}$ & $\begin{array}{c}\mathbf{C d} \\
(\mu \mathrm{g} / \mathrm{g})\end{array}$ & $\begin{array}{c}\mathbf{N i} \\
(\mu \mathrm{g} / \mathrm{g})\end{array}$ \\
\hline $\mathbf{1 N}$ & 24.00 & & 20.00 & 4.80 & 20.00 & 4.00 & 2.12 \\
\hline $\mathbf{2 N}$ & 12.01 & 5.25 & 32.50 & 7.30 & 8.75 & 2.10 & 3.20 \\
\hline $\mathbf{3 N}$ & 29.70 & 11.25 & 28.66 & 3.34 & 5.90 & 2.70 & 1.25 \\
\hline $\mathbf{4 N}$ & 11.37 & 7.00 & 19.85 & 4.05 & 8.75 & ----- & 2.50 \\
\hline $\mathbf{5 N}$ & 18.10 & 6.01 & 20.00 & 1.62 & 16.00 & 4.00 & 3.00 \\
\hline $\mathbf{6 N}$ & 13.21 & 6.07 & 17.50 & 1.40 & 10.00 & 2.40 & 1.90 \\
\hline $\mathbf{1 S}$ & 10.31 & 11.98 & 24.33 & 3.40 & 8.75 & 1.65 & 1.25 \\
\hline $\mathbf{2 S}$ & 14.50 & 4.11 & 56.25 & 4.72 & 6.25 & 3.75 & 2.25 \\
\hline $\mathbf{3 S}$ & ----- & 3.97 & ----- & 3.12 & 1.98 & ----- & 3.52 \\
\hline
\end{tabular}


(c) Addition method.

\begin{tabular}{|c|c|c|c|c|c|c|c|}
\hline Sample No. & $\begin{array}{c}\mathbf{Z n} \\
(\mu \mathrm{g} / \mathrm{g})\end{array}$ & $\begin{array}{c}\mathbf{C u} \\
(\mu \mathrm{g} / \mathrm{g})\end{array}$ & $\begin{array}{c}\mathbf{F e} \\
(\mu \mathrm{g} / \mathrm{g})\end{array}$ & $\begin{array}{c}\mathbf{M n} \\
(\mu \mathrm{g} / \mathrm{g})\end{array}$ & $\begin{array}{c}\mathbf{P b} \\
(\mu \mathrm{g} / \mathrm{g})\end{array}$ & $\begin{array}{c}\mathbf{C d} \\
(\mu \mathrm{g} / \mathrm{g})\end{array}$ & $\begin{array}{c}\mathbf{N i} \\
(\mu \mathrm{g} / \mathrm{g})\end{array}$ \\
\hline $\mathbf{1 N}$ & 23.75 & 7.50 & 21.50 & 5.00 & 17.5 & 5.00 & 3.00 \\
\hline $\mathbf{2 N}$ & ---- & ---- & ---- & --- & ---- & ---- & ---- \\
\hline $\mathbf{3 N}$ & ---- & ---- & ---- & --- & ---- & ---- & ---- \\
\hline $\mathbf{4 N}$ & ---- & ---- & ---- & --- & ---- & ---- & ---- \\
\hline $\mathbf{5 N}$ & ---- & ---- & ---- & --- & ---- & ---- & ---- \\
\hline $\mathbf{6 N}$ & ---- & ---- & ---- & ---- & ---- & ---- & ---- \\
\hline $\mathbf{1 S}$ & ---- & ---- & ---- & --- & ---- & ---- & ---- \\
\hline $\mathbf{2 S}$ & 10.94 & 5.50 & 52.50 & 5.00 & 5.06 & 4.50 & 2.50 \\
\hline $\mathbf{3 S}$ & ---- & ---- & ---- & --- & ---- & ---- & ---- \\
\hline
\end{tabular}

From the two methods of calibration the concentrations of the determined elements obtained from the analytical calibration curve are in good agreement with those obtained from the standard addition curve, which indicates the absence of matrix interference.

The obtained concentrations for $\mathrm{Zn}, \mathrm{Pb}$, and $\mathrm{Cd}$ by wet ash method are higher than the obtained by dry ash method. This is due to high temperature (450-600 $\left.{ }^{\circ} \mathrm{C}\right)$ increasing to complete the ashing process, which causes partial or complete loss by volatilization of many trace elements.

The detection limits, calculated using the standard deviation of the measurement for the sample blank and the slope of the standard (aqueous) calibration curve (10) $(3 \times$ s.d / slope $)$.

In the attempt to get the precision of the present method, the absorbance for an appropriate concentration in standard solutions for different elements was repeatedly measured. The relative standard deviation (RSD) for 10 replicate measurements was calculated. Table (4) illustrates the values obtained for detection limits and precision for every determined element. 
Table (4): Values obtained for limits of detection, precision and sensitivity

\begin{tabular}{|c|c|c|c|c|}
\hline \multirow{2}{*}{ Element } & \multirow{2}{*}{ RSD (\%) } & \multirow{2}{*}{ D.L } & \multicolumn{2}{|l|}{ Sensitivity } \\
\cline { 4 - 5 } & & & Measured & Literature \\
\hline $\mathrm{Mn}$ & 0.596 & 0.025 & 0.06 & 0.05 \\
$\mathrm{Zn}$ & 0.634 & 0.0014 & 0.02 & 0.02 \\
$\mathrm{Cd}$ & 1.260 & 0.015 & 0.04 & 0.25 \\
$\mathrm{~Pb}$ & 1.050 & 0.160 & 0.50 & 0.50 \\
$\mathrm{Ni}$ & 0.918 & 0.150 & 0.15 & 0.12 \\
$\mathrm{Fe}$ & 1.160 & 0.063 & 0.15 & 0.10 \\
$\mathrm{Cu}$ & 0.822 & 0.065 & 0.15 & 0.10 \\
\hline
\end{tabular}

\section{Conclusion:}

From the results obtained in this work, the following conclusion can be made. The samples were taken during the period of two years from summer 1998 to autumn 2000. It was observed from the obtained results that the elements, concentration in autumn 2000 is lower than that in summer 1998, for the fresh water samples. This may be attributed to the higher respiratory rate of fish in summer since fish use huge amounts of water due to the low dissolved oxygen content in water and to their higher feeding rate on plants and grasses during summer. The low metal content in fish in autumn is due to less activity of fish during this season.

The high Cu concentration in fish is usually caused by the use of copper sulphate to kill bilharzias snails in the River Nile in summer. Some elements (Fe and $\mathrm{Zn}$ ) concentration in the seawater is higher. This may be attributed to pollutant residuals of ships. The limits of detection achieved for the determined elements are very satisfactory. Their values lie between $0.0014 \mu \mathrm{gml}^{-1}$ for $\mathrm{Zn}$ to $0.16 \mu \mathrm{gml}^{-1}$ for $\mathrm{Pb}$. The values obtained for the precision lie between $0.596 \%$ and $1.26 \%$ for $\mathrm{Mn}$ and $\mathrm{Cd}$ respectively indicates the reliability of this technique. Maximum value of sensitivity achieved for $\mathrm{Zn}$ was $0.02 \mathrm{ppm}$ an excellent agreement has been found between the measured sensitivity and sensitivity in literature ${ }^{(11)}$.

\section{References:}

1. A.S. Parasad and D. Oberleas (Eds), "Trace elements in Human Health and Disease", vols. I and II, Academic press, New York (1976).

2. N. Kharasch (Ed), "Trace Metals in Health and Disease", Raven press, New York, (1979). 
3. G.S. Fell and T.D.B. Lyon, "Trace Elements Analysis in Biological Specimens", Elsevier, Amstardam, pp. 541 - 561 (1994).

4. O. Platteau and M. Carillo, Feul 74/5, 761 (1995).

5. S.E. Kakulu, O. Sibanjo and S.O. Ajayi, Int. J. Environ. Anal. Chem 30/3, 209 (1987).

6. I.Novozamsky, V.J.G. Houba, H.J. Vander Lee, R. Vaneck and M.D. Mignorance, Commun. Soil. Sci. Plant Anal. 24/19, 2595 (1993).

7. J. Merzwa, Yc. Sun, Yt. Chung and M.H. Yang Talanda, Oxford, 47, 5, 1263 (1998).

8. D.A. Laried, R.H. Dowdy and R.C. Munter, J. Anal. Atom. Spectrom., 5, 515 (1990).

9. R. Goodall, M.E. Foulkes and Les Ebdon; Spectro chim. Acta; 48B, 1563 (1993).

10. J. Jaganathan and I. Aggarwal, Applied spectroscopy. 47(2), 190 (1993).

11. G.F. KirKbright and M. Sargent, "Atomic Absorption and Fluorescence Spectroscopy" Academic Press, London, New York and San Francisco. (1974). 